\title{
POTENSI BAKTERI PELARUT FOSFAT DAN DIAZOTROF DARI RHIZOSFER KELAPA SAWIT TANAH GAMBUT SAPRIK TERHADAP PERTUMBUHAN BIBIT KELAPA SAWIT
}

\author{
(The Potential of Phosphate Solubilizing and Diazotrophic Bacteria from Oil Palm Rhizosphere on \\ Sapric Peat towards Palm Oil Seedling Growth) \\ IDA NUR ISTINA ${ }^{1 *}$, HAPPY WIDIASTUTI², HERI WIDIANTO ${ }^{1}$ \\ ${ }^{1}$ Balai Pengkajian Teknologi Pertanian Riau, Jl Kaharudin Nst 341, Pekanbaru \\ 2 Pusat Bioteknologi Riset Perkebunan Nusantara, Jl. Kencana, Bogor \\ *Email: idanuristina@gmail.com
}

\begin{abstract}
Utilization of biological fertilizer has the potential to reduce inorganic fertilizer application in oil palm cultivation. The aims of this research to obtain the potential of phosphate $(P)$ solubilizing and diazotrophic bacteria from oil palm rhizosphere towards palm oil seedling growth. This research has been done on Sapric peat soil at Pelalawan Regency, Riau Province from June to November 2014, using a factorial randomized block design ( $3 \times 5$ with 3 replications). The first factor were the potential bacteria isolates ( $10=$ without isolates; 11 = Isolate T5.1 + T7. I2 = Isolate T9.1 + T5); the second factor were NPK fertilizer dosage ( $1-100 \% ; p 2=85 \% ; p 3=70 \%$ fertilizer and $p 4=55 \%$ recommended fertilizer). The results showed that sapric peat soil was a potential source of $P$ solubilizing bacteria with the ability to solubilized of $P$ up to $329.94 \mathrm{ppm}$, and diazotrophic bacteria with the ability of $\mathrm{N}$-fixation up to $0.0293 \mathrm{mmol} / \mathrm{L} / \mathrm{hr}$. Application of $70 \% \mathrm{~N}$ and $P$ fertilizers and i2 isolate provides the best vegetative growth performance of oil palm seedlings and reduces $30 \%$ of inorganic fertilizers application.
\end{abstract}

Keywords: phosphate solubilizing bacteria, diazotrophic bacteria, rhizosphere, oil palm, peat

\section{PENDAHULUAN}

Perluasan areal pertanian mengarah pada lahan-lahan sub optimal seperti lahan gambut. Sampai tahun 2017 luasan perkebunan kelapa sawit di Indonesia meliputi 14 juta hektar (Direktorat Jendral Perkebunan, 2018), 1.7 juta hektar di antaranya diusahakan di lahan gambut (Rehman et al., 2015). Beberapa kendala pengembangan pertanian di lahan gambut yaitu kering tidak balik, derajat kemasaman, rendahnya ketersediaan hara bagi tanaman, kadar abu dan tata air (Saragih, 2016), serta adanya asam-asam fenolat yang bersifat meracun bagi tanaman (Noor dan Masganti, 2016). Untuk meningkatkan produktivitas lahan gambut dapat dilakukan melalui pengelolaan tata air, dan pemupukan

Aplikasi pemupukan anorganik secara terus menerus dapat mengakibatkan menurun nya tingkat kesuburan tanah dan keragaman biota tanah, kerentanan tanaman terhadap serangan hama dan penyakit, pencemaran produk pertanian yang berdampak pada kesehatan manusia (Savci, 2012), serta menyebabkan penurunan efisiensi input produksi. Hajjam and Cherkaoui (2017) menyebutkan bahwa penggunaan pupuk kimia berbasis fosfat menyebabkan terjadnya polusi pada tanah dan air, dan apabila berinteraksi dengan unsur $\mathrm{Mg}, \mathrm{Ca}$, Fe akan mengendap di permukaan tanah, sehingga menyebabkan penurunan ketersediaan $P$. Selain itu pemenuhan dalam jumlah besar untuk mendongkrak hasil tidak dapat dilakukan petani dikarenakan ketidaktersediaan modal dan kelangkaan pupuk di lapangan.

Upaya peningkatan efisiensi dan produktivitas lahan sub optimal dapat dilakukan dengan pendayagunaan potensi biologi tanah yang berperanan dalam peningkatan ketersediaan dan transformasi hara penunjang pertumbuhan tanaman (Herman dan Dibyo, 2013). Pemanfaatan mikroba potensial sebagai pupuk hayati meningkatkan efisiensi input produksi khususnya pemupukan (Ajmal et al., 2018) melalui mekanisme interaksinya dalam penyediaan hara bagi tanaman di rhizosfer (Okur, 2018). Di alam keberadaan mikroba fungsional tersedia melimpah termasuk di lahan gambut berupa fungi maupun bakteri. Penggunaan mikroba diazotrof maupun pelarut $\mathrm{P}$ dapat mengurangi aplikasi pupuk $\mathrm{N}$ dan $\mathrm{P}$, sehingga mengurangi biaya produksi dan sangat sesuai untuk perkebunan rakyat dengan kemampuan finansial terbatas. Hasil penelitian (Nurhidayati dan Permatasari, 2014) 
menunjukkan bahwa aplikasi inokulasi bakteri pelarut $\mathrm{P}$ dan diazotrof pada pertanaman cabai mampu memperbaiki pertumbuhan tanaman. Hasil penelitian Hidayat et al. (2018) menyebutkan bahwa aplikasi bakteri diazotrof mampu meningkatkan efektivitas penggunaan pupuk N sampai $25 \%$. Selain itu, penggunaan mikroba secara simultan juga meningkatkan daya dukung lahan terhadap mikroba antagonis yang dapat menekan perkembangan penyakit lahan (Moriri et al., 2015). Penelitian ini bertujuan untuk mengetahui potensi bakteri pelarut fosfat dan diazotrof dari rhizosfer kelapa sawit terhadap pertumbuhan bibit kelapa sawit.

\section{BAHAN DAN METODA}

Penelitian telah dilaksanakan di Lahan Gambut yang ditanami Kelapa Sawit di Kabupaten Pelalawan Provinsi Riau dari bulan Juni sampai November 2014 menggunakan Rancangan Acak Kelompok Faktorial 3x5 dengan 3 kali ulangan. Sebagai faktor pertama adalah mikroba potensial (Io= tanpa isolat; $I 1=$ Isolat T5.1+T7; I2= Isolat T9.1+T5; Faktor ke dua adalah dosis pupuk NPK (p1- $100 \%$ pupuk anjuran; p2= $85 \%$ pupuk anjuran; p3=70 \% pupuk anjuran dan p4= $55 \%$ pupuk anjuran).

Pupuk anorganik yang digunakan adalah pupuk NPK dengan dosis anjuran $25 \mathrm{~g}$

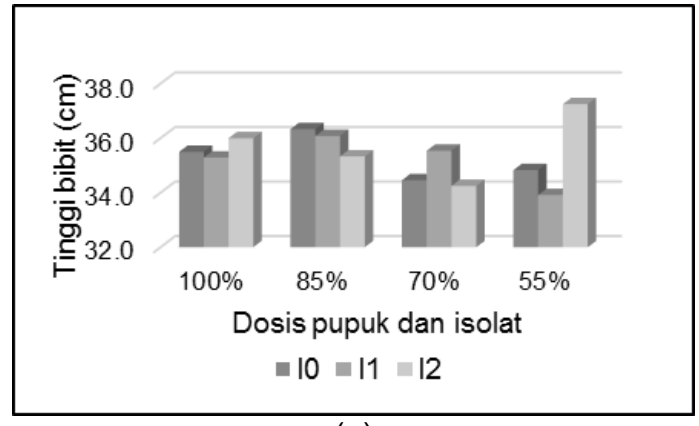

(a) untuk 200 tanaman. Sebelum diaplikasikan pupuk dilarutkan dalam 10 I air. Aplikasi pupuk NPK dilakukan sehari sebelum aplikasi isolat bakteri potensial. Isolat bakteri yang digunakan adalah isolat bakteri pelarut fosfat dan diazotrof yang berasal dari rhizosfer tanaman kelapa sawit asal gambut saprik di Kabupaten Pelalawan pada kedalaman $0-20 \mathrm{~cm}$ yang telah diisolasi dan dikarakterisasi (Ginting, dkk, 2006), serta diuji antagonis di laboratorium Biotek PT. Riset Perkebunan Nusantara. Aplikasi isolat bakteri potensial dilakukan dengan cara mengocor suspensi bakteri sebanyak $15 \mathrm{ml}\left(10^{9} \mathrm{sel} \mathrm{ml}^{-1}\right.$ polybag- $\left.^{-1}\right) \mathrm{di}$ sekitar perakaran tanaman bibit kelapa sawit umur 3 bulan pada pagi hari sebelum matahari terbit. Parameter yang diamati meliputi pertumbuhan tinggi tanaman $(\mathrm{cm})$; jumlah daun (helai), panjang daun $(\mathrm{cm})$ dan berat brangkasan (g). Data yang terkumpul ditabulasikan dan dianalisis menggunakan perangkat lunak SPSS ver 19.

\section{HASIL DAN PEMBAHASAN}

Hasil pengamatan lapang menunjukkan bahwa aplikasi isolate bakteri pelarut $\mathrm{P}$ dan penambat $\mathrm{N}$ non simbiotik asal rhizosfer kelapa sawit berpotensi untuk dimanfaatkan dalam meningkatkan ketersediaan hara dan keragaan pertumbuhan

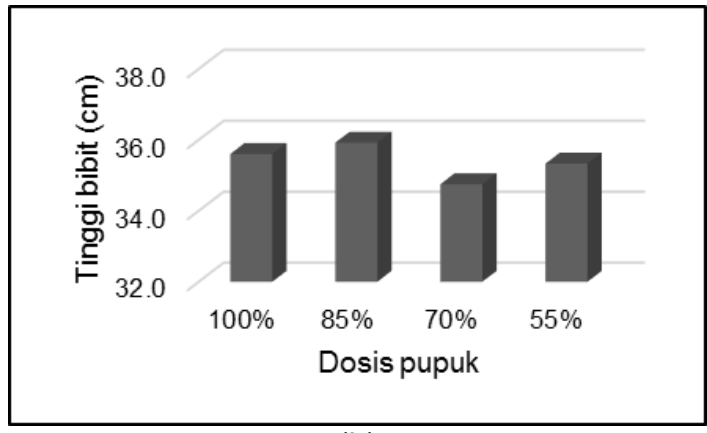

(b)

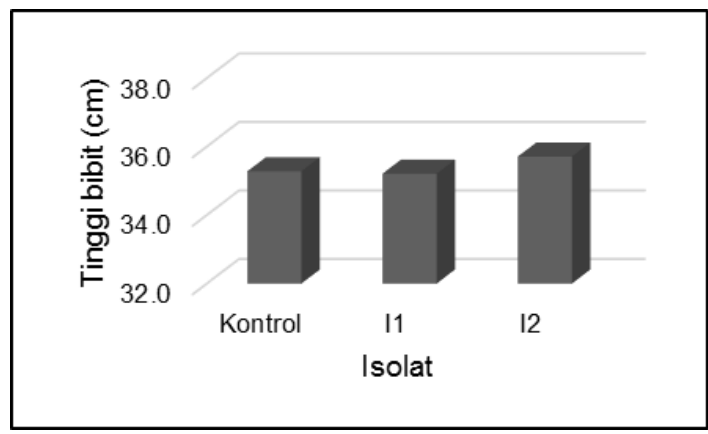

(c)

Gambar 1. Pengaruh Dosis pemupukan anorganik dan aplikasi isolat bakteri terhadap pertumbuhan tinggi bibit tanaman kelapa sawit (a); Pengaruh aplikasi pupuk N,P dan K terhadap pertumbuhan bibit kelapa sawit (b); Pengaruh aplikasi isolat bakteri pelarut $\mathrm{P}$ dan diazotrof terhadap pertumbuhan tinggi bibit tanaman kelapa sawit (c). 
tanaman kelapa sawit.

\section{Tinggi Tanaman}

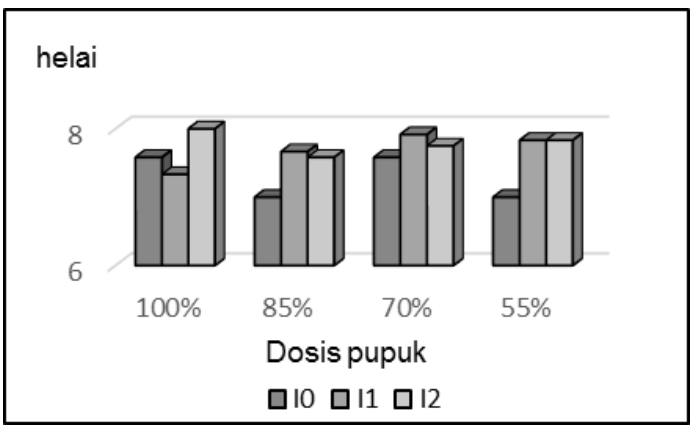

(a)
Gambar 1 menunjukkan bahwa pemupukan $55 \% \mathrm{~N}$ dan $\mathrm{P}$ dan inokulan isolat $\mathrm{i}_{2}$ diikuti perlakuan pemupukan $85 \%$ pupuk $\mathrm{N}$ dan $\mathrm{P}$ memberikan keragaan tinggi tanaman

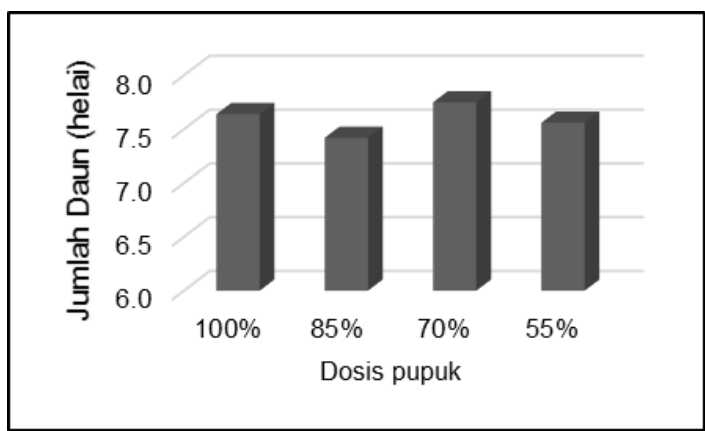

(b)

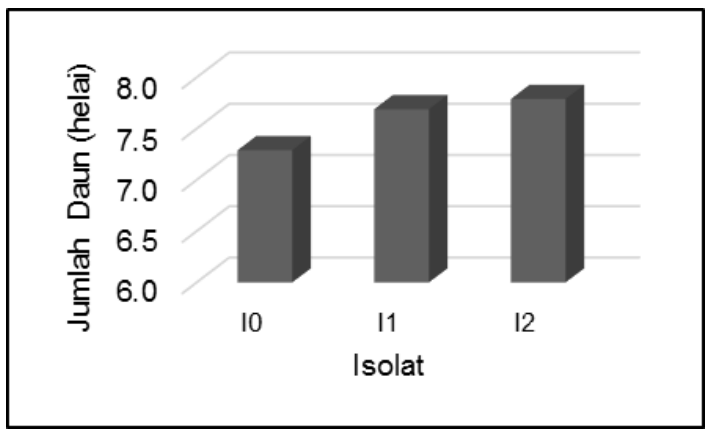

(c)

Gambar 2. Pengaruh Dosis pemupukan anorganik dan isolat terhadap pertambahan jumlah daun bibit kelapa sawit (a); Pengaruh aplikasi pupuk N,P,K terhadap pertambahan jumlah daun kelapa sawit (b); Pengaruh aplikasi isolat bakteri pelarut $\mathrm{P}$ dan diazotrof terhadap pertambahan jumlah daun bibit kelapa sawit (c).

Hasil analisis statistika tidak menunjukkan adanya interaksi antara pemupukan dan aplikasi isolat bakteri penambat $\mathrm{N}$ dan pelarut $\mathrm{P}$ terhadap tinggi tanaman, demikian juga pengaruh mandirinya (Gambar 1). Pertumbuhan tanaman memerlu kan unsur hara $\mathrm{N}$ dan $\mathrm{P}$ dalam jumlah yang cukup dan seimbang, namun demikian pertumbuhan tanaman juga dipengaruhi oleh sifat genetik tanaman (Yugi Rahayu and Harjoso, 2011). Pada kondisi pertanaman kecil kebutuhan hara $\mathrm{N}$ dan $\mathrm{P}$ belum diperlukan dalam jumlah besar, sehingga aplikasi pupuk $\mathrm{N}$ dan $\mathrm{P}$ serta inokulasi bakteri pelarut $\mathrm{P}$ dan diazotrof pada bibit kelapa sawit di lokasi penelitian telah mencukupi kebutuhan tanaman. Hal tersebut mengakibatkan penambahan jumlah takaran tidak mempengaruhi pertumbuhan tinggi tanaman. Aplikasi isolat bakteri pelarut $P$ dan diazotrof belum menunjukkan pengaruhnya secara nyata. Hal tersebut seiring dengan pendapat Birnadi (2012) yang menyatakan penambahan BPF pada kedelai tidak nyata mempengaruhi tinggi tanaman. tertinggi berturut-turut $37,25 \mathrm{~cm}$ dan $36,33 \mathrm{~cm}$ sedangkan pemupukan $70 \%$ dan inokulan menggunakan isolat $\mathrm{i}_{2}$ menunjukkan keragaan tinggi tanaman terendah $(34,25 \mathrm{~cm})$. Hal ini diduga dikarenakan $\mathrm{pH}$ tanah yang rendah yaitu 3,5 yang tidak sesuai untuk aktivitas bakteri yang akan tumbuh dengan baik pada kondisi mendekati netral. Bakteri pelarut fosfat pada beberapa jenis tanah bertahan pada kisaran pH 4 - 8 dan 5 - 9 (Gainey, 2018). Mekanisme pelarutan fosfat dilakukan bakteri dengan menghasilkan asam organik. Isolat yang dapat menghasilkan asam-asam organik tersebut akan mengakibatkan penurunan $\mathrm{pH}$ tanah. Amirrullah and Prabowo (2017) menyebutkan bahwa derajat $\mathrm{pH}$ berpengaruh terhadap kondisi kimia tanah dan ketersediaan unsur hara terutama fosfat. Lebih lanjut Nazemi et al. (2012) menyebutkan bahwa pad lahan masam memiliki kandungan Al, Fe tinggi yang mengkelat unsur hara $P$, sehingga tidak tersedia meskipun secara alami $\mathrm{P}$ tersedia dalam jumlah besar di alam.

Hara nitrogen merupakan hara potensial yang diperlukan oleh tanaman untuk tumbuh dan berkembang. Di alam kandungan 
hara $\mathrm{N}$ ditentukan oleh keberadaan bahan organik dan $\mathrm{pH}$ tanah. Pada $\mathrm{pH}$ optimal mikroba diazotrof akan bekerja (Zheng et al., 2019), sedangkan Azotobacter mendekomposisi bahan organik dan menyediakan hara bagi tanaman, Pemupukan nitrogen dalam bentuk akan menurunkan $\mathrm{pH}$ tanah yang menyebabkan tidak efektifnya mikroba untuk beraktivitas, sebaliknya pada takaran $55 \%$ diduga menyebabkan penurunan $\mathrm{pH}$ yang tidak terlalu rendah dan kandungan bahan organik pada tanah gambut mengakibatkan isolat diazotrof dapat bekerja dengan baik dalam menyediakan hara nitrogen untuk dapat diserap oleh tanaman yang diindikasikan oleh tingginya tanaman.

Secara tunggal, pemupukan $\mathrm{N}$ dan $\mathrm{P}$ $85 \%$ memberikan pengaruh terbaik terhadap pertumbuhan tinggi tanaman dan terendah pada dosis $\mathrm{N}$ dan $\mathrm{P} 70 \%$ artinya untuk pertumbuhan tinggi tanaman, asupan hara $85 \% \mathrm{~N}$ dan $\mathrm{P}$ mencukupi kebutuhan tanaman. bibit kelapa sawit lebih baik dibandingkan isolat $\dot{i}_{1}$. Hal ini menunjukkan bahwa pendayagunaan isolat $i_{2}$ lebih mampu beradaptasi terhadap lingkungan dan berkontribusi dalam penyediaan hara untuk pertumbuhan bibit kelapa sawit. Setiap isolat memiliki kemampuan beradaptasi terhadap lingkungan yang berbeda. Kemampuan adaptasinya terhadap lingkungan mempengaruhi ke mampuannya dalam berkontribusi menyedia kan hara bagi tanaman.

Aplikasi secara bersamaan dengan pemupukan anorganik $\mathrm{N}$ dan $\mathrm{P}$ menunjukkan bahwa inokulan $\mathrm{i}_{2}$ memberikan pengaruh yang baik terhadap pertumbuhan tinggi tanaman pada dosis pupuk $\mathrm{N}$ dan $\mathrm{P} 55 \%(37,250 \mathrm{~cm})$, sedangkan $\mathrm{i}_{1}(\mathrm{~T} 5.1+\mathrm{T} 5)$ memberikan keragaan yang tidak lebih baik dibandingkan kontrol. Hal ini menunjukkan bahwa aplikasi mikroba pelarut fosfat dan diazotrof berkontribusi terhadap penyediaan hara dan pertumbuhan

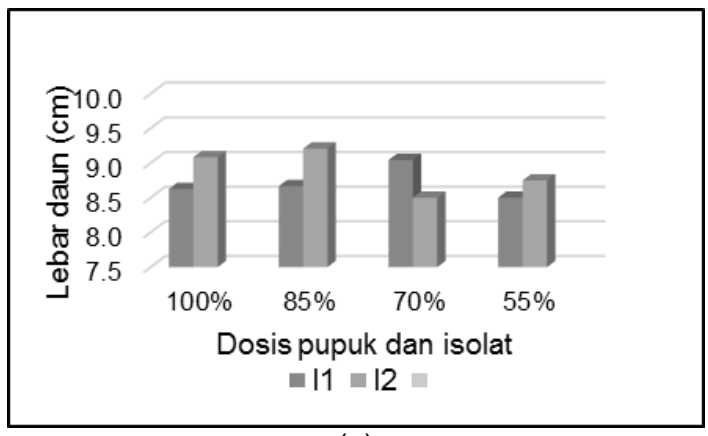

(a)

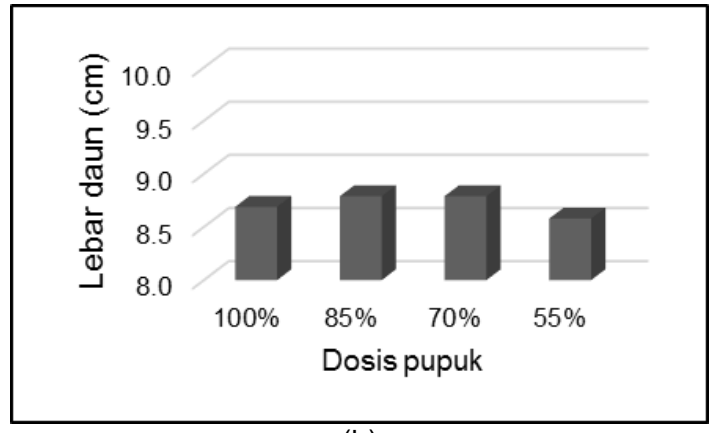

(b)

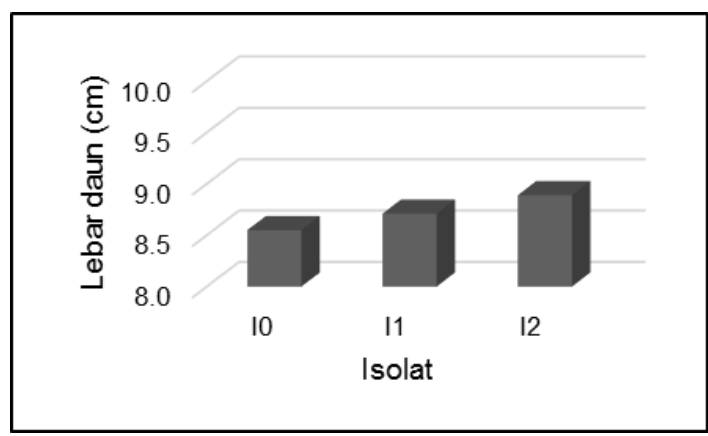

(c)

Gambar 3. Pengaruh Dosis pemupukan anorganik dan isolat bakteri pelarut $\mathrm{P}$ dan penambat $\mathrm{N}$ terhadap pertambahan lebar daun daun bibit kelapa sawit (a); Pengaruh Dosis pemupukan anorganik terhadap pertambahan lebar daun daun bibit kelapa sawit (b); Pengaruh aplikasi isolat bakteri pelarut $P$ dan diazotrof terhadap pertambahan lebar daun bibit kelapa sawit (c).

Kandungan hara N, P, K, Ca, Mg pada tanah gambut pada umumnya berada pada jumlah yang tinggi, namun adanya asam-asam organik yang yang dihasilkan oleh bahan pembentuk gambut menyebabkan hara tersebut tidak tersedia bagi tanaman.

Isolat $i_{2} \quad(T 9.1+T 5)$ secara tunggal memberikan kontribusi terhadap pertumbuhan bibit tanaman (Bano and Mohamad I.S., 2016) dan (Purwani and Elsanti, 2016). Hasil penelitian (Herman 2013) Memperlihatkan perlakuan Mikroba Pelarut Fosfat (MPF) + NPK menghasilkan tinggi tanaman, bobot biomassa, dan serapan $P$ tertinggi dibandingkan perlakuan lainnya. Isolat MPF yang dikombinasikan dengan pemberian NPK 
mampu meningkatkan serapan hara $\mathrm{P}$ oleh benih kakao sampai 3,07 kali.

\section{Jumlah Daun}

Hasil analisis statistika menunjukkan bahwa tidak terdapat interaksi antara pemupukan dan inokulasi bakteri pelarut fosfat dan diazotrof terhadap jumlah daun bibit kelapa sawit, namun secara mandiri aplikasi isolat mempengaruhi pertambahan jumlah daun bibit kelapa sawit, meskipun isolat $i_{1}$ dan $\mathrm{i}_{2}$ tidak berbeda nyata satu sama lain. Secara tunggal, pemupukan anorganik $70 \%$ dosis anjuran memberikan mempengaruhi pertambahan jumlah daun terbanyak $(7,75$ helai) diduga dikarenakan bahwa pada dosis tersebut telah mencukupi kebutuhan bibit untuk melakukan metabolisme. Pada perlakuan pemupukan $100 \% \mathrm{~N}$ dan $\mathrm{P}+$ inokulasi $\mathrm{i}_{2}$ dan pemupukan $70 \%+\mathrm{i}_{1}$ diikuti perlakuan pemupukan $55 \%$ pupuk $\mathrm{N}$ dan $\mathrm{P}+$ isolat $i_{1}$, dan $i_{2}$ sedangkan jumlah daun paling sedikit terdapat pada perlakuan kontrol (Gambar 2). Secara tunggal dosis pupuk N dan $\mathrm{P} 70 \%$ memberikan pertambahan jumlah daun terbanyak $(7,75$ lembar) diikuti dosis pupuk $\mathrm{N}$ dan $\mathrm{P} 100 \%$ (7,64 lembar), dosis pupuk $\mathrm{N}$ dan $\mathrm{P} 55 \%$ (7,56 lembar) dan terendah dosis pupuk $\mathrm{N}$ dan $\mathrm{P} 85 \%(7,42$ lembar). Inokulan $\mathrm{i}_{2}$ secara tunggal memberikan kontribusi pertambahan jumlah daun tertinggi $(7,79$ lembar $)$ yang tidak lembar). Hal ini menunjukkan bahwa aplikasi isolate bakteri pelarut fosfat dan penambat $\mathrm{N}$ pada bibit kelapa sawit memberikan pertumbuhan tanaman yang lebih baik dibandingkan dengan tanpa inokulasi.

\section{Lebar Daun}

Hasil analisis statistika menunjukkan bahwa tidak terdapat interaksi antara pemupukan dan inokulasi bakteri penambat $\mathrm{N}$ dan pelarut $\mathrm{P}$ terhadap lebar daun bibit kelapa sawit demikian juga dengan pengaruh mandirinya. Secara tunggal dosis pupuk $\mathrm{N}$ dan P $70 \%$ menunjukkan kontribusi terhadap pertambahan lebar daun paling baik $(8,79 \mathrm{~cm})$ meskipun tidak berbeda lebar daun pada dosis pupuk $\mathrm{N}$ dan P $80 \%(8,79 \mathrm{~cm})$ dan terendah pada dosis pemupukan $55 \%(8,58 \mathrm{~cm})$ hal ini kemungkinan dikaitkan dengan kecukupan hara yang diperlukan tanaman untuk metabolisme tanaman yang menghasilkan fotosintat yang akan dibagikan ke bagian tanaman, salah satunya untuk pertambahan lebar daun. Semakin kecukupan hara yang tersedia bagi tanaman maka semakin lebar daun. Dosis N dan P $70 \%$ dari dosis anjuran masih mencukupi kebutuhan hara yang diperlukan oleh bibit kelapa sawit, sehingga pemberian dosis yang lebih tinggi akan hilang, karena menguap ataupun tercuci dan terikat oleh asam-asam organik gambut menjadi hara yang tidak tersedia.

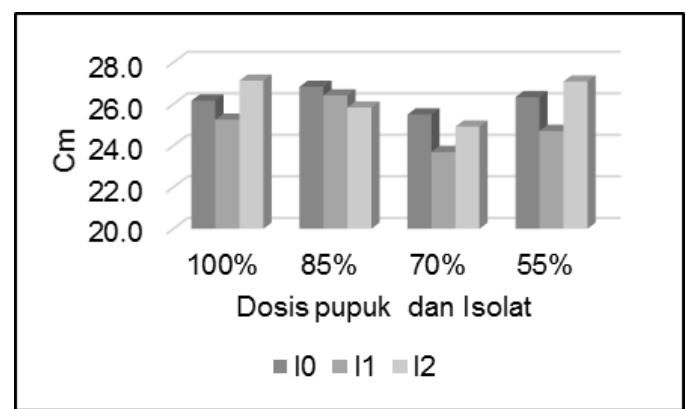

(a)

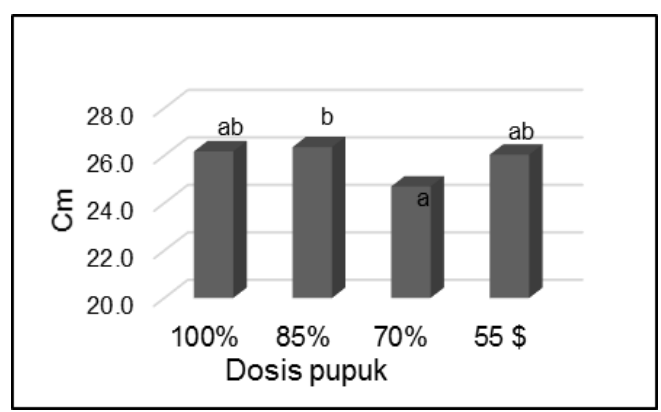

(b)

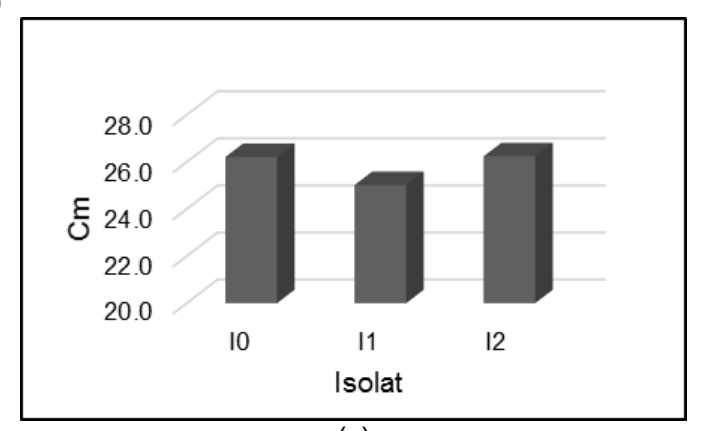

(c)

Gambar 4. Pengaruh Dosis pemupukan anorganik dan isolat bakteri pelarut $\mathrm{P}$ dan penambat $\mathrm{N}$ terhadap pertambahan panjang daun daun bibit kelapa sawit (b); Pengaruh Dosis pemupukan anorganik terhadap pertambahan panjang daun daun bibit kelapa sawit (b); Pengaruh aplikasi isolat bakteri pelarut $\mathrm{P}$ dan diazotrof terhadap pertambahan panjang daun bibit kelapa sawit (c).

berbeda dengan $\mathrm{i}_{1}$ dibandingkan $\mathrm{i}_{0} \quad(7,29$ 
Peranan inokulan bakteri diazotrof dan pelarut $P$ dapat disampaikan bahwa inokulan $\mathrm{i}_{2}$ memberikan kontribusi yang paling tinggi $(8,89$ $\mathrm{cm})$ dibandingkan inokulan $\mathrm{i}_{1}(8,71 \mathrm{~cm})$ maupun kontrol $(8,55 \mathrm{~cm})$ (Gambar 3$)$. Hal ini kemungkinan berkaitan dengan kemampuannya beradaptasi dengan lingkungan dan kemampuannya dalam melakukan tugasnya untuk menambat $\mathrm{N}$ dan melarutkan fosfat yang diperlukan oleh tanaman.

Secara bersama-sama lebar daun terlebar terdapat pada perlakuan pemupukan $80 \% \mathrm{~N}$ dan $\mathrm{P}+$ inokulan isolat $\mathrm{i}_{2}(9,208 \mathrm{~cm})$, diikuti dengan perlakuan pemupukan 100\% pupuk $\mathrm{N}$ dan $\mathrm{P}+$ inokulan isolat $\mathrm{i}_{2}(9,083 \mathrm{~cm})$, pemupukan $70 \%$ pupuk $\mathrm{N}$ dan $\mathrm{P}+$ inokulan isolat $i_{1} \quad(9,042 \mathrm{~cm})$. Hal ini menunjukkan bahwa $85 \%$ dosis pupuk $\mathrm{N}$ dan $\mathrm{P}+$ isolat $\mathrm{i}_{2}$ atau aplikasi $70 \%$ pupuk $\mathrm{N}$ dan $\mathrm{P}+$ isolat $\mathrm{i}_{1}$ telah memberikan pertumbuhan bibit yang baik; artinya bibit kelapa sawit memerlukan asupan hara dalam jumlah tinggi namun demikian dikaitkan dengan efisiensi pemupukan maka aplikasi isolat $i_{1}$ dan isolat $\mathrm{i}_{2}$ dapat menurunkan penggunaan pupuk anorganik sebesar 15 hingga 30\%.

\section{Panjang Daun}

Hasil analisis statistika menunjukkan bahwa tidak terdapat interaksi antara pemupukan dan inokulasi bakteri penambat $\mathrm{N}$ dan pelarut $P$ terhadap panjang daun bibit kelapa sawit namun demikian dosis pupuk $\mathrm{N}$ dan $\mathrm{P}$ mempengaruhi panjang daun.

Secara tunggal pemupukan $85 \%$ pupuk $\mathrm{N}$ dan $\mathrm{P}$ memberikan keragaan panjang daun terpanjang $26,36 \mathrm{~cm}$, berbeda nyata dengan pemupukan $70 \% \mathrm{~N}$ dan $\mathrm{P}(27,70 \mathrm{~cm})$.
Aplikasi isolat bakteri diazotrof dan pelarut $P$ secara tidak langsung mempengaruhi ketersediaan hara yang diperlukan tanaman untuk menghasilkan fotosintat dan proses penyerapan hara melalui perbaikan pertumbuhan akar tanaman. Hasil pengamatan di lapangan dapat diketahui bahwa Isolat $i_{2}$ memberikan kontribusi terhadap panjang daun terpanjang $(26,24 \mathrm{~cm})$ dibandingkan inokulan $i_{1}(25,02 \mathrm{~cm})$ dan kontrol. Aplikasi secara bersamaan antara dosis pupuk dan inokulasi isolat bakteri penambat $\mathrm{N}$ dan pelarut $\mathrm{P}$ menunjukkan bahwa isolat $i_{1}$ memberikan pengaruh terbaik pada pemupukan $80 \% \mathrm{~N}$ dan $\mathrm{P}$ dan terendah pada dosis pupuk $70 \%(23,458 \mathrm{~cm})$, sedangkan isolat $\mathrm{i}_{2}$ memberikan pengaruh terbaik pada dosis $100 \%$ pupuk $\mathrm{N}$ dan $\mathrm{P}$ $(27,125 \mathrm{~cm})$ tidak berbeda nyata dengan dosis $55 \%$ pupuk $\mathrm{N}$ dan $\mathrm{P}(27,083)$. Artinya bahwa isolat $i_{2}$ dapat beraktivitas dengan baik pada dosis pemupukan 55\%, sehingga dapat mengurangi kebutuhan pupuk hingga $45 \%$, sedangkan isolat $i_{1}$ dapat menurunkan input produksi pupuk $\mathrm{N}$ dan $\mathrm{P}$ sampai $15 \%$.

\section{Berat Brangkasan}

Hasil analisis statistika menunjukkan bahwa tidak terdapat interaksi antara aplikasi dosis pemupukan dan isolat bakteri diazotrof dan pelarut $P$, demikian juga dengan pengaruh mandirinya. Gambar 5 menunjukkan bahwa dosis $70 \%$ pupuk $\mathrm{N}$ dan $\mathrm{P}$ memberikan keragaan diameter kanopi tertinggi yaitu 39,71 $\mathrm{cm}$. Hal ini menunjukkan bahwa penambahan $70 \%$ pupuk NPK pada tanah gambut telah memenuhi kebutuhan tanaman, penambahan jumlah pupuk hingga $100 \%$ dosis tidak diperlukan karena hanya sebagian kecil hara

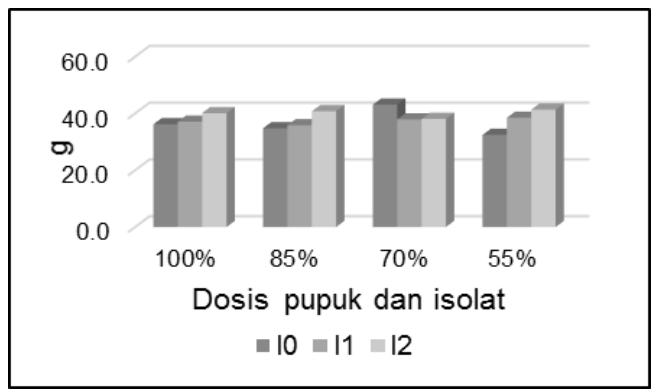

(a)

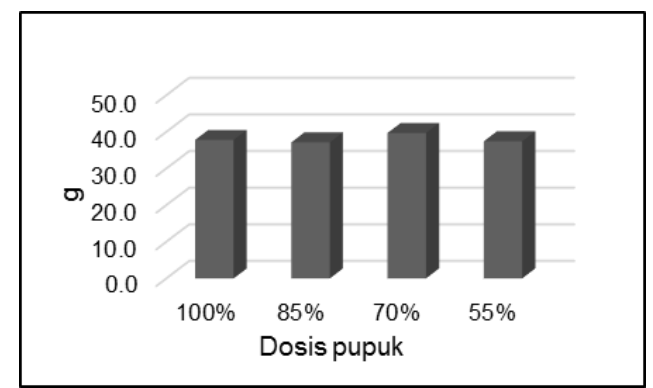

(b)

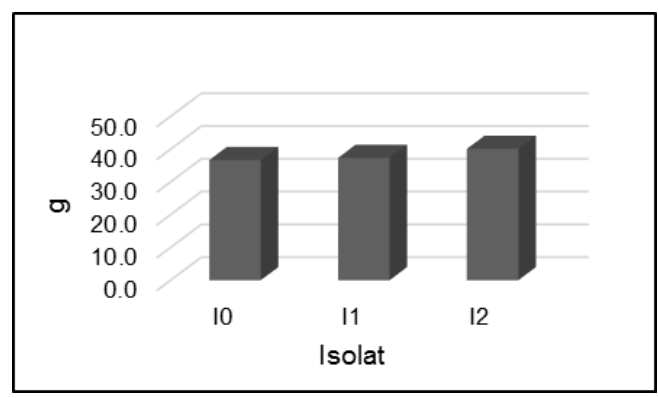

(c)

Gambar 5. Pengaruh Dosis pemupukan anorganik terhadap berat kering brangkasan bibit kelapa sawit (a); Pengaruh aplikasi pupuk NPK terhadap berat kering brangkasan kelapa sawit (b); Pengaruh aplikasi isolat bakteri pelarut $\mathrm{P}$ dan penambat $\mathrm{N}$ terhadap berat kering brangkasan bibit kelapa sawit (c). 
yang dapat diserap tanaman. Aplikasi isolat bakteri pelarut $P$ dan diazotrof menunjukkan adanya kontribusi secara tidak langsung terhadap bobot brangkasan, di mana isolat $i_{2}$ secara tunggal memberikan kontribusi tertinggi yaitu $40.08 \mathrm{gr}$ diikuti isolat $\mathrm{i}_{1}$ dan terendah pada kontrol.

Aplikasi secara bersama-sama menunjukkan bahwa isolat $i_{2}$ sudah menunjukkan keragaan berat brangkasan terbaik pada dosis pupuk $55 \%$ demikian juga dengan isolat $i_{2}$. Artinya bahwa baik isolat $i_{1}$ maupun $\mathrm{i}_{2}$ berpotensi mengurangi penggunaan input produksi.

\section{Serangan Hama dan Penyakit}

Hama yang menyerang pembibitan kelapa sawit di lokasi penelitian adalah hama ulat dan belalang sedangkan penyakit yang menyerang adalah penyakit bercak daun yang disebabkan oleh jamur Curvularia sp. (Gambar kebutuhan hara tanaman, sedangkan pada tanaman yang tidak diinokulasi isolat bakteri potensial memiliki berat serangan terkecil. Hal tersebut diduga diakibatkan oleh kurangnya hara yang menyebabkan daun menjadi keras, sehingga kurang disukai oleh hama dan penyakit.

Aplikasi isolat bakteri pelarut $\mathrm{P}$ dan diazotrof pada bibit tanaman kelapa sawit menyebabkan serangan hama dan penyakit lebih tinggi dibandingkan dengan tanpa perlakuan (Gambar 6); rata-rata serangan $0,014 \%$ dan $0,011 \%$ oleh belalang, $0,009 \%$ dan $0,008 \%$ oleh ulat dan $0,012 \%$ dan $0,010 \%$ oleh penyakit bercak daun. Secara tunggal isolat $\mathrm{i}_{2}$ menunjukkan rata-rata serangan hama belalang, ulat dan penyakit paling tinggi $(0,016 \% ; 0,011 \%$ dan $0,013 \%)$ dibandingkan $i_{1}$ $(0,012 \% ; 0,007 \%$ dan $0,010 \%)$ dan kontrol $(0,011 \% ; 0,008 \%$ dan $0,010 \%)$. Hal tersebut kemungkinan diakibatkan oleh kontribusi hara

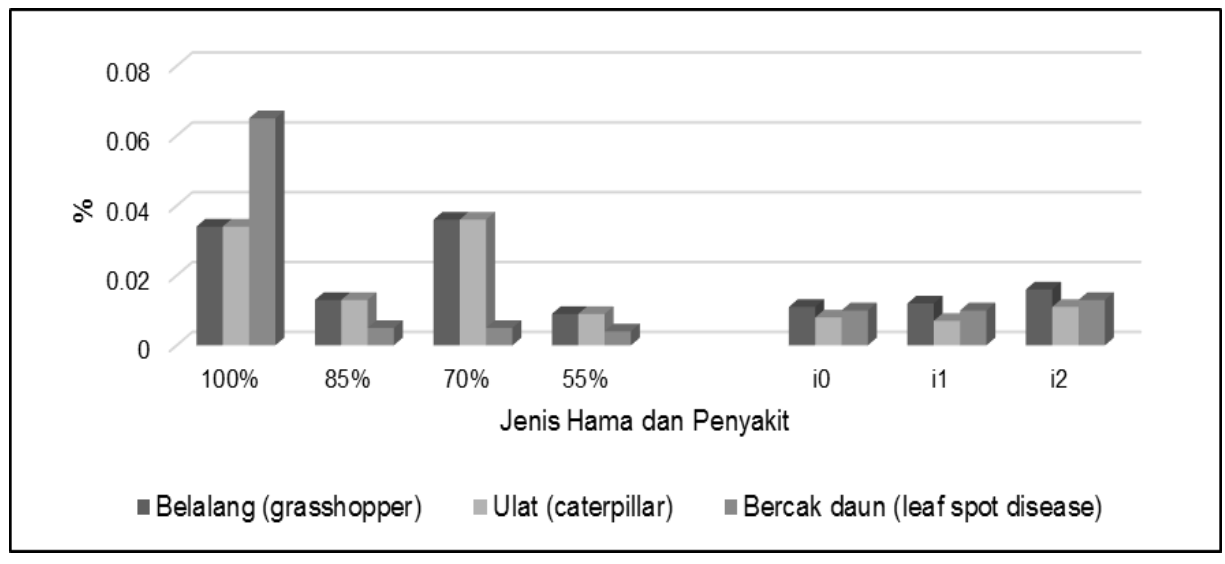

Gambar 6.Persentase serangan hama dan penyakit

6). Rata-rata serangan hama baik ulat maupun belalang paling tinggi adalah pada pemupukan dengan dosis $70 \% \mathrm{~N}$ dan $\mathrm{P}$ sebesar $0,036 \%$ sedangkan terendah pada dosis $55 \% \mathrm{~N}$ dan $\mathrm{P}$ sebesar $0,009 \%$, demikian juga serangan penyakit bercak daun. Pada dosis $100 \%$ pupuk $\mathrm{N}$ dan $\mathrm{P}$ anorganik menyebabkan serangan penyakit yang paling tinggi, Hal ini diduga dikaitkan dengan suburnya tanaman yang menyebabkan meningkatnya kelembaban lingkungan, sehingga penyakit dapat berkembang dengan baik. Menurut Susanti dan Elza (2019) bahwa perubahan iklim menyebabkan terjadinya kerentanan tanaman terhadap serangan hama dan penyakit. Kondisi kecukupan nitrogen dalam tanaman juga menyebabkan daun menjadi sumber pakan utama dan lebih disukai oleh hama belalang dan ulat setelah inangnya punah.

Aplikasi isolat bakteri diazotrof dan pelarut $P$ mempengaruhi besarnya serangan, hal ini kemungkinan oleh kecukupan hara $N$ dan $P$ yang disumbangkan untuk memenuhi yang diberikan, sehingga mengakibatkan daun menjadi rentan terhadap serangan hama dan penyakit, meskipun masih jauh dari ambang ekonomi. Serangan penyakit Curvularia diduga selain kelembaban dan adanya tanaman teki yang merupakan inang dari Curvularia (Fauzi dan Murdan, 2009). Kenyataan lapang menunjukkan bahwa sebelum dilakukan penelitian di daerah lokasi penelitian banyak terdapat tanaman inang, namun dengan adanya kegiatan penelitian menyebabkan dihilangkannya tanaman inang, sehingga hama menyerang bibit kelapa sawit untuk memenuhi asupan pakan yang diperlukan untuk pertumbuhan dan perkembangannya.

\section{KESIMPULAN}

Berdasarkan hasil penelitian yang telah dilakukan dapat disimpulkan $70 \%$ pupuk $\mathrm{N}$ dan $\mathrm{P}$ dan aplikasi isolat $\mathrm{i}_{2}$ memberikan keragaan pertumbuhan vegetatif bibit kelapa 
sawit terbaik dan menurunkan $30 \%$ penggunaan pupuk anorganik.

\section{DAFTAR PUSTAKA}

Ajmal, M., H. I. Ali, R. Saeed, A. Aktar, M. Tahir, M. Z. M. and A. Ayub. 2018. Biofertilizer as an Alternative for Chemical Fertilizers. Research \& Reviews: Journal of Agriculture and Allied Sciences, 7(1): 1-7.

Amirrullah, J. dan A. Prabowo. 2017. Dampak Keasaman Tanah Terhadap Ketersediaan Unsur Hara Fosfor Di Lahan Rawa Pasang Surut Kabupaten Banyuasin. pp. 978-979. Dalam Prosiding Seminar Nasional Lahan Suboptimal, Palembang, 19-20 Oktober 2017

Bano, S. A. and S. M. Iqbal. 2016. Biological Nitrogen Fixation to Improve Plant Growth and Productivity. International Journal of Agriculture Innovations and Research, 4(4): 596-599.

Birnadi, S. 2012. Respons Tanaman Padi Organik (Oryza sativa L.) terhadap Bakteri Pelarut Fosfat (BPF) dan Mikoriza Vesikular Arbuskular (MVA). Jurnal ISTEK. 6(1-2): 71-84.

Permatasari, A. D. dan Nurhidayati, T. (2014). Pengaruh Inokulan Bakteri Penambat Nitrogen Pertumbuhan Tanaman Cabai Rawit. Pengaruh Inokulan Bakteri Penambat Nitrogen, Bakteri Pelarut Fosfat dan Mikoriza Asal Desa Condro, Lumajang, Jawa Timur terhadap Pertumbuhan Tanaman Cabai Rawit. Jurnal Sains dan Seni Pomits, 3(2): 4448.

Direktorat Jenderal Perkebunan. 2018. Program Pembangunan Perkebunan 2018. Available at: http://ditjenbun.pertanian .go.id.

Fauzi, T. M. dan Murdan. 2009. The Role of Secondary Fungal Pathogens in Increasing Biocontrol Ability. Crop Agro, 2(2): 152-157.

Gainey, P. L. 2018. Soil Reaction and the Growth of Azotobacter. The Journal of Agricultural Research, XIV(7): 265-271.

Ginting, R. C. B., Saraswati, R. and Husen, E. 2006. Mikroorganisme pelarut fosfat. Balai Besar Sumberdaya Lahan Pertanian Badan Penelitian dan Pengembangan Pertanian: Bogor. 149p

Hajjam, Y. and S. Cherkaoui. 2017. The influence of phosphate solubilizing microorganisms on symbiotic nitrogen fixation: Perspectives for sustainable agriculture. Journal of Materials and Environmental Science, 8(3): 801-808.
Herman, M. dan P. Dibyo. 2013. Pengaruh Mikroba Pelarut Fosfat terhadap Pertumbuhan dan Serapan Hara P Benih Kakao (Theobroma cacao L.). Jurnal Balittri. 2(4): 129-138.

Moriri, S., L. G. Owoeye, and I. K. Mariga. 2015. Evaluation of Maize Nutrient Contents in a Maize/Cowpea Intercropping Systems in South Africa. Journal Advances in Plants \& Agriculture Research, 2(6): 250-253.

Kaburuan R., Hapsoh dan Gusmawartati. 2014. Isolasi Dan Karakterisasi Bakteri Penambat Nitrogen Non-Simbiotik Tanah Gambut Cagar Biosfer Giam Siak Kecil-Bukit Batu.Jurnal Agrotropika, 5(1): 35-39.

Noor, M., dan F. A. Masganti. 2016. Lahan gambut Indonesia. Pembentukan, karakteristik, dan potensi mendukung ketahanan pangan (Edisi revisi). Revisi II. Jakarta: IAARD Pres.253 p

Nazemi, D., A. Hairani. dan Nurita. 2012. Optimalisasi Pemanfaatan Lahan Rawa Pasang Surut Melalui Pengelolaan Lahan dan Komoditas. Jurnal Agrovivor, 5(1): 52-57.

Okur, N. 2018. A Review: Bio-FertilizersPower of Beneficial Microorganisms in Soils'. Biomedical Journal of Scientific and technical research, 4(4): 4028-4029.

Purwani, J. dan Elsanti. 2016. Inokulasi Mikroba Penambat Nitrogen dan Pelarut Fosfat Tunggal serta Konsorsia pada Kedelai Varietas Grobogan di Tanah Ultisol Rangkasbitung. pp: 218-225. Makalah Seminar Hasil Penelitian Tanaman Aneka Kacang dan Umbi. Malang

Rehman, S. A. U., S. Sabiham, U. Sudadi and S. Anwar. 2015. Impacts of Oil Palm Plantations on Climate Change: $A$ Review of Peat Swamp Forests' Conversion in Indonesia. International Journal of Plant \& Soil Science, 4(1): 117.

Saragih, J. M. 2016. Pengelolaan Lahan Gambut di Perkebunan Kelapa Sawit di Riau. Buletin Agrohorti, 4(3):312-320

Savci, S. 2012. Investigation of Effect of Chemical Fertilizers on Environment. APCBEE Procedia 1(2012): 287-292.

Susanti, E., E. Surmaini, dan W. Estiningtyas. 2019. Parameter Iklim sebagai Indikator Peringatan Dini Serangan Hama Penyakit Tanaman. Jurnal Sumberdaya lahan, 12(1): 59-70.

Rahayu, A. Y and T. Harjoso. 2011. Aplikasi Abu Sekam pada Padi Gogo (Oryza sativa L.) terhadap Kandungan Silikat dan Prolin Daun serta Amilosa dan 
Jurnal Agroteknologi, Vol. 10 No. 2, Februari 2020 : 67 - 75

Protein Biji. Journal of Biota, 16(1): 4855.

Zheng, B. X. D. P. Zhang, Y. Wang, X. L. Hao, M. A. M. Wadaan, W. N. Hozzein, J. Penuelas, Y. G. Zhu and X. R. Yang.
2019. Responses to soil pH gradients of inorganic phosphate solubilizing bacteria community. Scientific Reports, 9(1): 1-8. 